\title{
Geochemical and microbiological characterization of sediments at the mouth of Río de las Minas (Punta Arenas, Chile)
}

\author{
Caracterización biogeoquímica de sedimentos bajo la influencia \\ antropogénica en la desembocadura del Río de las Minas (Punta Arenas, Chile)
}

Vladimir Bermanec ${ }^{1}$, Željka Fiket ${ }^{2}$, Jasna Hrenović ${ }^{1}$,
Snježana Kazazić ${ }^{3}$, Goran Kniewald ${ }^{2}$, Chantelle Venter ${ }^{4}$ \& André Botha ${ }^{4}$

\section{Abstract}

The appearance and spread of antibiotic resistance are considered a highly complex process with many factors affecting the resistance mechanisms, including metals. In order to fully understand the spread of antibiotic resistance in different environments, combined studies including geochemistry and microbiology are becoming imperative. So far, very few such studies have been conducted, and none of them involves the southernmost regions. The aim of this study was, therefore, to examine the biogeochemical characteristics of sediments of the southernmost part of Chile. Sediment geochemistry, as well as the presence of heterotrophic and carbapenemresistant bacteria $(\mathrm{CRB})$ in the Río de las Minas and neighbouring Strait of Magellan in Punta Arenas (Chile), was investigated to assess the anthropogenic impact of untreated urban wastewater on the accumulation of metals and microbial contaminants in this coastal system. Geochemistry of sediments indicated the influence of both natural processes and anthropogenic activities. Although levels of metals in sediments currently do not represent a toxic effect on organisms, the anthropogenic influence on the sediment composition in the study area cannot be denied. Clinically relevant $\mathrm{CRB}$ were found in river sediments (1.9 and $2.7 \log \mathrm{CFU} / \mathrm{mL}$ ). Our findings suggest that the Río de las Minas is under the anthropogenic impact of untreated urban wastewater and represent a significant source of potentially pathogenic CRB to the local environment.

\section{Key words:}

biogeochemistry, carbapenem-resistant bacteria, metals, sediment geochemistry.

\section{Resumen}

La aparición y propagación de la resistencia a los antibióticos se considera un proceso muy complejo, con muchos factores que afectan a los mecanismos de resistencia, incluidos los metales. Con el fin de comprender plenamente la propagación de la resistencia a los antibióticos en diferentes entornos, es imprescindible realizar estudios combinados que incluyan geoquímica y microbiología. Hasta ahora, se han realizado muy pocos estudios de este tipo y ninguno de ellos afecta a las regiones más meridionales. El objetivo de este estudio fue, por lo tanto, examinar las características biogeoquímicas de los sedimentos del extremo sur de Chile. Se investigó la geoquímica de los sedimentos, así como la presencia de bacterias heterótrofas y resistentes a los carbapenemas (BRC) en el Río de las Minas y el Estrecho de Magallanes en Punta Arenas (Chile), para evaluar el impacto antropogénico de las aguas

1 University of Zagreb, Faculty of Science, Zagreb, Croatia.

2 Ruđer Bošković Institute, Division for Marine and Environmental Research, Zagreb, Croatia.

$\gg$ zeljka.fiket@irb.hr

3 Ruđer Bošković Institute, Division of Physical Chemistry, Zagreb, Croatia.

4 Laboratory for Microscopy \& Microanalysis, University of Pretoria, Pretoria, South Africa. 
residuales urbanas no tratadas sobre la acumulación de metales y contaminantes microbianos en este sistema costero. La geoquímica de los sedimentos indicaba la influencia tanto de los procesos naturales como de las actividades antropogénicas. Aunque los niveles de metales en los sedimentos actualmente no representan un efecto tóxico sobre los organismos, no se puede negar la influencia antropogénica sobre la composición de los sedimentos en el área de estudio. Se encontraron CCR clínicamente relevantes en los sedimentos de los ríos (1,9 y 2,7 UFC logarítmicos/ $\mathrm{ml})$. Nuestros hallazgos sugieren que el Río de las Minas está bajo el impacto antropogénico de las aguas residuales urbanas no tratadas y representa una fuente significativa de CRB potencialmente patógena para el medio ambiente local.

\section{Palabras clave:}

biogeoquímica, bacterias resistentes al carbapenem, metales, geoquímica de sedimentos.

\section{INTRODUCTION}

Effluents from hospitals, domestic sewage, urban runoff, as well as industrial waste represent a significant source of various contaminants for the receiving environment when discharged into sewage systems, rivers, lakes and sea without the prior treatment (Spindler et al. 2012; Mwanamoki et al. 2014; Devarajan et al. 2015). The lack of purification of urban wastewater prior to their release to a natural recipient contributes not only to the load of toxic elements and various organic pollutants (Zheng et al. 2008; Reczynski et al. 2010; Devarajan et al. 2015), but also represents an epidemiological pathway for the spread of pathogenic bacteria, including antibiotic-resistant bacteria (ARB) and antibiotic-resistance genes (ARGs). Namely, the use, misuse, and abuse of antimicrobials from the 1940s onwards led to the emergence of populations of antimicrobial-resistant pathogenic bacteria (Meletis, 2016). Consequently, the increasing number of $\mathrm{ARB}$, in particular bacteria resistant to carbapenems, has become a major challenge in drug therapy in humans and animals (WHO, 2015). Namely, carbapenems represent a class of antibiotic agents with the broadest spectrum of activity and greatest potency against Grampositive and Gram-negative bacteria. A variety of environmental bacterial species possess intrinsic resistance to carbapenem. However, the intrinsic resistance to carbapenems is not common among clinically important bacteria, which is why the clinical isolates of carbapenem-resistant bacteria (CRB) became the global healthcare problem (Meletis, 2016). Over years, CRB were not only reported in hospital wastewaters (Ferreira et al. 2011; Zhang et al. 2013; Chandran et al. 2014), but have also been recently isolated from raw and secondary treated municipal wastewater (Hrenovic et al. 2016, 2017), and show an overall increasing frequency of occurrence. For example, carbapenem resistance of Acinetobacter baumannii clinical isolates soared in Croatia from $10 \%$ in 2008 to $87 \%$ in 2015 (CAMS, 2016), and in Sweden, from two cases reported in 2008 to 46 cases of carbapenem-resistant Enterobacteriaceae in 2014 (Hellman et al. 2014).

In February 2017, the World Health Organization (WHO) published its first ever list of antibiotic-resistant "priority pathogens", which specifies 12 families of bacteria that pose the greatest threat to human health. On that list, the carbapenem-resistant Acinetobacter baumannii, Pseudomonas aeruginosa, and Enterobacteriaceae rank as "Priority 1: Critical" (WHO, 2017). Even though a number of studies confirm the presence of CRB in hospital and municipal wastewaters (Ferreira et al. 2011; Zhang et al. 2013; Chandran et al. 2014; Hrenovic et al. 2016), they are not quantitative and preclude broader assessment of CRB population spread from wastewaters to the environment. Nonetheless, dissemination of CRB from clinics via the hospital and urban wastewater to the river has recently been reported in Croatia (Šeruga Musić et al. 2017).

The type of urban wastewater and its consequent influence on the natural recipient may vary according to the lifestyle of inhabitants. Given that the extent of antibiotic resistance in the bacterial communities has been frequently linked to anthropogenic activities in an associated environment, the bacteria in areas with limited human activity are expected to contain fewer antibiotic-resistance genes (Rabbia et al. 2016). An example of such environment is the Antarctic continent, where, until recently, bacteria had negligible or no antibiotic resistance (Skurnik et al. 2006; Bonnedahl et al. 2008; Cowan 
et al. 2011). Increase in anthropogenic impact with touristic and scientific activities resulted in presence of coliforms, such as Escherichia coli, near sewage outfalls in this region (Delille \& Delille, 2000; Delille \& Gleizon, 2003). Recent studies confirmed the presence of antibioticresistance in $E$. coli isolated from the seawater around Fildes Peninsula in Antarctica (Rabbia et al. 2016), raising further concern, especially considering the high $E$. coli counts and the multidrug resistance in the majority of strains. Namely, the strains isolated from the seawater originated from one of the local wastewater treatment plants discharging into nearby Maxwell Bay (Rabbia et al. 2016). The presence of these strains naturally increases with the intensity and the type of anthropogenic pressure. Fildes Peninsula concentrates many National Antarctic Programs stations and scientific facilities due to the nearby Chilean Lt. Marsh Airfield (Three Chilean Stations, Chinese Great Wall, Korean King Sejong, Russian Bellingshausen, and Uruguayan Artigas). Recent studies conducted on the wastewater from pharmaceutical facilities in South-western Nigeria revealed that almost all the bacterial isolates (more than 96\%) from the wastewater treatment plant as well as from the discharge points for the final effluents exhibited multidrug-resistance (Obayiuwana et al. 2018). Similar findings were reported for Cauvery River Basin (Tiruchirappalli, Tamil Nadu, India) river sediments, up and downstream from the Indian treatment plant near Hyderabad, where a high prevalence of resistance genes from multiple classes of antibiotics was identified (Kristiansson et al. 2011; Marathe et al. 2018).

According to Pote et al. (2010), sediments may contain 100-1000 fold higher bacterial counts than the overlying water. Thus, estimation of microbial contaminants in sediments can serve as a stable index for long-term water quality risks (Pote et al. 2010; Thevenon et al. 2012; Mwanamoki et al. 2014; Devarajan et al. 2015; Devarajan et al. 2016). Moreover, sediments provide insight into the persistence of microbial contaminants/ARGs and the potential impact of the emergence of resistant bacteria from wastewaters and its transfer to the water microbial community (Devarajan et al. 2016).
The emergence and spread of antibiotic resistance are considered a very complex process with many factors, including metals, affecting co-selection and cross-selection of resistance (Devarajan et al. 2016; Imran et al. 2019). Namely, metals (such as $\mathrm{Cd}, \mathrm{Cu}, \mathrm{Hg}$ and $\mathrm{Zn}$ ) can selectively induce the co-selection of antibiotic resistance if they spread and accumulate in the environment at critical concentrations (Seiler et al. 2012; Devarajan et al. 2015; Imran et al. 2019). Studies investigating the distribution of river sediments as a potential reservoir of toxic metals, ARBs and ARGs are still very limited in southernmost areas, including south Chile. The aim of the presented research was, therefore, to assess the anthropogenic influence of untreated urban wastewaters on the accumulation of metal and microbial contaminants in the sediment of the Río de las Minas and adjacent Strait of Magellan waters in Punta Arenas, Chile. The objectives of the study were to determine the sedimentological, mineralogical and geochemical characteristics of sediments in the study area and to investigate the presence of heterotrophic and carbapenem-resistant bacteria.

\section{MATERIALS AND METHODS}

\section{Site description}

Punta Arenas is the capital city of Chile's southernmost region, Magallanes and Antártica Chilena (Fig. 1a, b). It is located on the eastern shore of the Brunswick Peninsula, the last peninsula of the American continent, facing the Straits of Magellan at almost equal distance from the Pacific and Atlantic Oceans. Due to its far southern latitude, Punta Arenas has a subpolar oceanic climate (Köppen climate classification, $\mathrm{Cfc}$ ) bordering on a tundra climate. The seasonal temperature in Punta Arenas is greatly moderated by its proximity to the ocean, with average lows in July near $-1^{\circ} \mathrm{C}\left(30{ }^{\circ} \mathrm{F}\right)$ and highs in January of $14^{\circ} \mathrm{C}\left(57^{\circ} \mathrm{F}\right)$. It is known for stable constant temperatures, which vary only slightly with the seasons. Rainfall is highest in April and May, and the snowy season runs all through the Chilean winter (June until September). As in most of Patagonia, average annual precipitation is quite low, only $380 \mathrm{~mm}$ (15 inches) because of a rain shadow created by the Andes. 


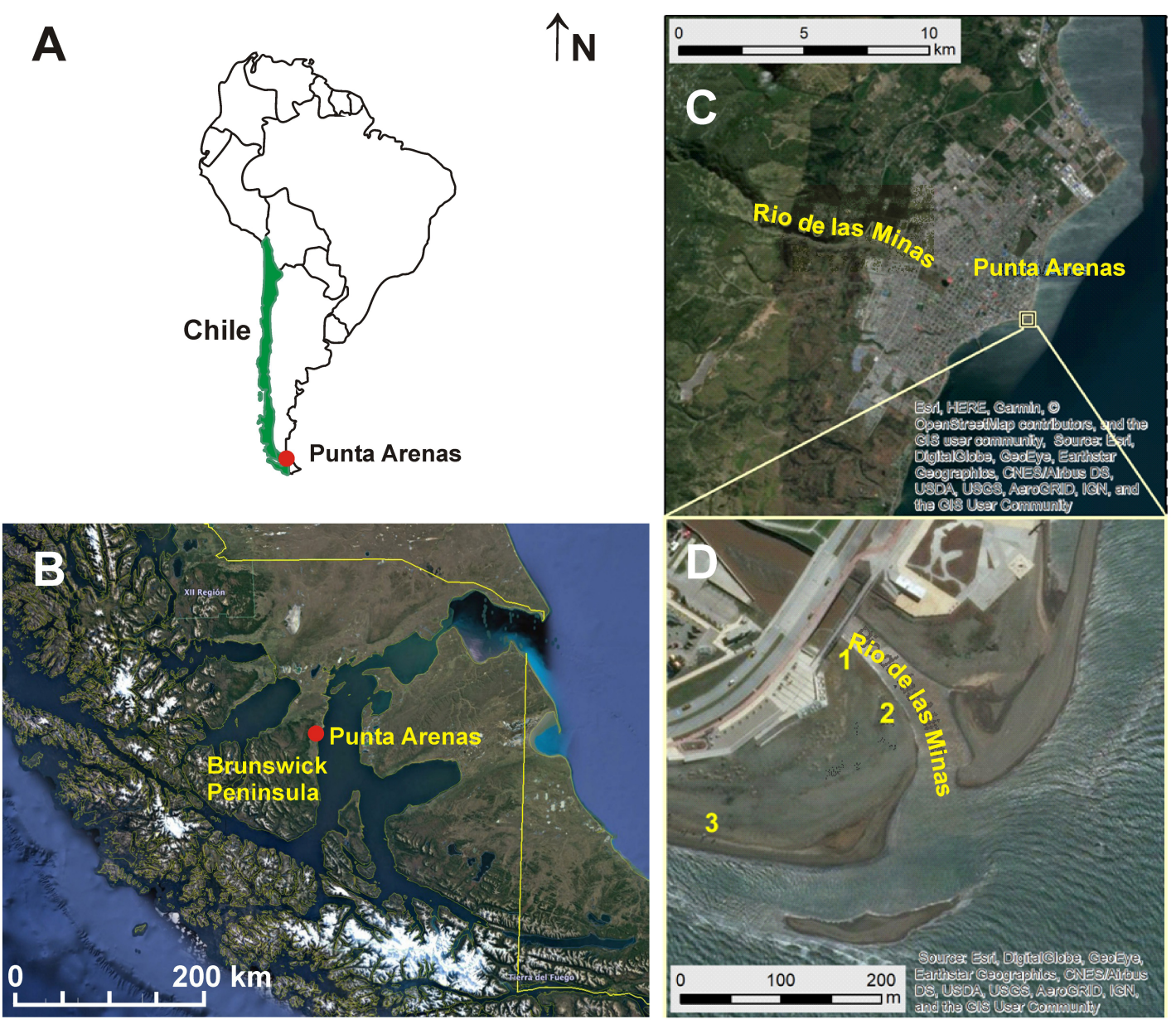

Fig. 1. Sampling stations at the mouth of the Río de las Minas (location 1 and 2) and the Strait of Magellan (location 3).

According to the last Census (in 2012) Punta Arenas has a population of about 125,000 inhabitants.

The untreated urban wastewaters are discharged into the Río de las Minas, which connects the Pacific and Atlantic sea through the Strait of Magellan.

\section{Sampling and sample preparation}

Sampling was conducted in April 2018 at the mouth of Río de las Minas in Punta Arenas (Fig. 1c, d). Surface sediment samples $(5 \mathrm{~cm})$ were collected with a sterile spatula and stored in plastic bottles. Samples were taken at a total of three locations, two from the river section $(1,2)$ and one from the shores of the Magellan Strait (3).
Samples were stored in closed bottles at room temperature for four days before laboratory analysis. For the purpose of the planned analyses, the required amount of each sample was separated and prepared as follows. For mineralogical and geochemical analysis, an aliquot of each sample was air dried and stored until further use. For bacteriological analyses, fresh sediment samples were suspended and diluted in sterile peptone water. For scanning electron microscopy, fresh sediment samples were taken and prepared according to the procedure described below.

\section{Grain size analysis}

Sediments were characterized by a laser diffraction particle size analyser (LS 13 320, 
Beckman Coulter, USA) for grain size distribution. Prior to grain size analysis, sediment samples were soaked briefly in deionised water and treated with ultrasound for $5 \mathrm{~min}$.

Sample texture and statistical granulometric parameters were identified and calculated using original Folk and Ward (1957) logarithmic graphical measures in GRADISTAT package (Blott \& Pye, 2001). Based on the particle size distribution, sediment samples were classified according to Shepard (1954).

\section{Mineralogical analysis}

Prior to analysis, sediment samples were milled and pressed into pellets. Mineral phases in samples were determined by X-ray powder diffraction (XRD) using a Philips X'pert powder diffractometer with $\mathrm{Cu}-\mathrm{K} \alpha$ radiation filtered with a graphite monocrystal monochromator. Powder diffraction patterns were identified and indexed using the ICDD Powder diffraction file (2004) database.

\section{Physico-chemical and multielement analyses}

The $\mathrm{pH}$ value of sediment was measured after suspension of sediment in distilled water (1:2.5) according to the Standard Methods for Examination of Water and Wastewater (APHA, AWWA \& WEF, 2005) by using a WTW pH meter with WTW SenTix81 electrode. The $\mathrm{pH}$ meter was calibrated with standard solutions, with a precision of $0.01 \mathrm{pH}$ unit.

Prior to multielement analysis, sediment samples $(0.05 \mathrm{~g})$, previously homogenised in an agate mill, were subjected to a total digestion in the microwave oven (Multiwave 3000, Anton Paar, Graz, Austria). The two-steps digestion procedure included the addition of a mixture of $4 \mathrm{~mL}$ nitric acid $\left(\mathrm{HNO}_{3}, 65 \%\right.$, pro analysi, Kemika, Zagreb, Croatia) - $1 \mathrm{~mL}$ hydrochloric acid $(\mathrm{HCl}, 36.5 \%$, pro analysi, Kemika, Zagreb, Croatia) - $1 \mathrm{~mL}$ hydrofluoric acid (HF, 48\%, pro analysi, Kemika, Zagreb, Croatia) to the samples followed by addition of $6 \mathrm{~mL}$ of boric acid $\left(\mathrm{H}_{3} \mathrm{BO}_{3}, 40 \mathrm{~g} \mathrm{~L}^{-1}\right.$, Fluka, Steinheim, Switzerland). Prior to analysis, samples were diluted, acidified with $2 \%(\mathrm{v} / \mathrm{v}) \mathrm{HNO}_{3}$ (65\%, supra pur, Fluka, Steinheim, Switzerland) and In $\left(1 \mu \mathrm{gL}^{-1}\right)$ as an internal standard was added. Detailed method description is given elsewhere (Fiket et al. 2017).

The multielement analysis of sediment samples was performed by High Resolution Inductively Coupled Plasma Mass Spectrometry (HR-ICP-MS) using an Element 2 instrument (Thermo, Bremen, Germany). Typical instrument conditions and measurement parameters used throughout the work were reported earlier (Fiket et al. 2017).

All samples were analysed for the total concentration of 25 elements (Ag, Al, As, Ba, $\mathrm{Be}, \mathrm{Bi}, \mathrm{Cd}$, Co, Cr, Cs, Cu, Fe, Li, Mn, Mo, Ni, $\mathrm{Pb}, \mathrm{Rb}, \mathrm{Sb}, \mathrm{Se}, \mathrm{Sr}, \mathrm{Ti}, \mathrm{U}, \mathrm{V}$ and $\mathrm{Zn}$ ). Quality control of analytical procedure was performed by simultaneous analysis of the blank and certified reference material for river sediment (Metranal-1, Analytika, Czech Republic), marine sediment (MESS-3, National Research Council Canada, Ontario, Canada) and offshore marine sediment (NCS DC 75301, China National Analysis Center for Iron and Steel, Beijing, China). A good agreement between the analysed and certified concentrations within their analytical uncertainties for all elements was obtained ( \pm $10 \%)$.

\section{Bacteriological analysis}

Bacteriological analyses were performed in triplicate. Aerobically grown total heterotrophic bacteria were determined on Nutrient agar (Biolife) after incubation at $22^{\circ} \mathrm{C} / 72 \mathrm{~h}$ (APHA et al. 2005). The CRB were determined on CHROMagar Acinetobacter supplemented with CR102 (CHROMagar), intended for the cultivation of clinically relevant carbapenem-resistant bacteria, after incubation at $35^{\circ} \mathrm{C} / 72 \mathrm{~h}$. The numbers of bacteria were determined as Colony Forming Units (CFU), logarithmically transformed, and expressed as log CFU per $1 \mathrm{~mL}$ of wet sediment. The prevalence of CRB among total heterotrophic bacteria was calculated as a percentage ratio of absolute numbers $\left(\mathrm{CFU}_{\mathrm{CRB}} / \mathrm{CFU}_{\text {heterotrophic }}\right) \times 100$.

The colonies of $\mathrm{CRB}$ were determined by matrix-assisted laser desorption ionization-time of flight mass spectrometry - MALDI-TOF MS (software version 3.0, Microflex LT, Bruker Daltonics). 


\section{SEM analysis}

Fresh sediment subsamples were fixed in $2.5 \%$ glutaraldehyde in phosphate buffered saline and prepared for scanning electron microscopy (SEM) using standard techniques. Briefly, after removal of the fixative, the samples were rinsed in phosphate buffer, post-fixed in $1 \%$ osmium tetroxide in phosphate buffer, again rinsed in phosphate buffer and then dehydrated in a graded ethanol series up to absolute ethanol. Cells for SEM were dried with hexamethyldisilazane and carbon coated before examination with a Zeiss Ultra PLUS FEG SEM at low voltage $(0.5 \mathrm{kV})$ at Laboratorium for electron microscopy and microanalysis of University of Pretoria.

\section{RESULTS}

\section{Sediment grain size and mineral composition}

The mean grain size $(\mathrm{Mz})$ in the Río de las Minas corresponds to very coarse silt (37.8 $\mu \mathrm{m})$ and medium sand $(254 \mu \mathrm{m})$ at location 1 and 2 , respectively. According to the grain size parameters, both river samples were very poorly sorted displaying unimodal and trimodal particle distribution at said locations, respectively. Particle size distribution in sediments from said locations is shown in Fig. 2. According to Shepard (1954), sediments can be classified as sandy mud at location 1 and silty sand at location 2 .

X-ray analyses of collected samples of sediment show the same mineral content. In spite of different shade and slightly finer granulation of sediment 1 , all sediments contain 4 main components: quartz, albite, montmorillonite, and sericite and probably subordinate quantity of organic compound.

\section{Sediment $\mathrm{pH}$ and element composition}

All sediment samples displayed a slight alkaline reaction, with sea sediment having the highest $\mathrm{pH}$ value (Table 1).

Results of measurement of 25 elements (Ag, $\mathrm{Al}, \mathrm{As}, \mathrm{Ba}, \mathrm{Be}, \mathrm{Bi}, \mathrm{Cd}$, Co, Cr, Cs, Cu, Fe, Li, Mn, $\mathrm{Mo}, \mathrm{Ni}, \mathrm{Pb}, \mathrm{Rb}, \mathrm{Sb}$, Se, Sr, Ti, U, V and $\mathrm{Zn}$ ) in sediment samples are shown in Table 1.

Sediment samples displayed same order of concentrations per element with the general decreasing trend from the river towards the ocean,

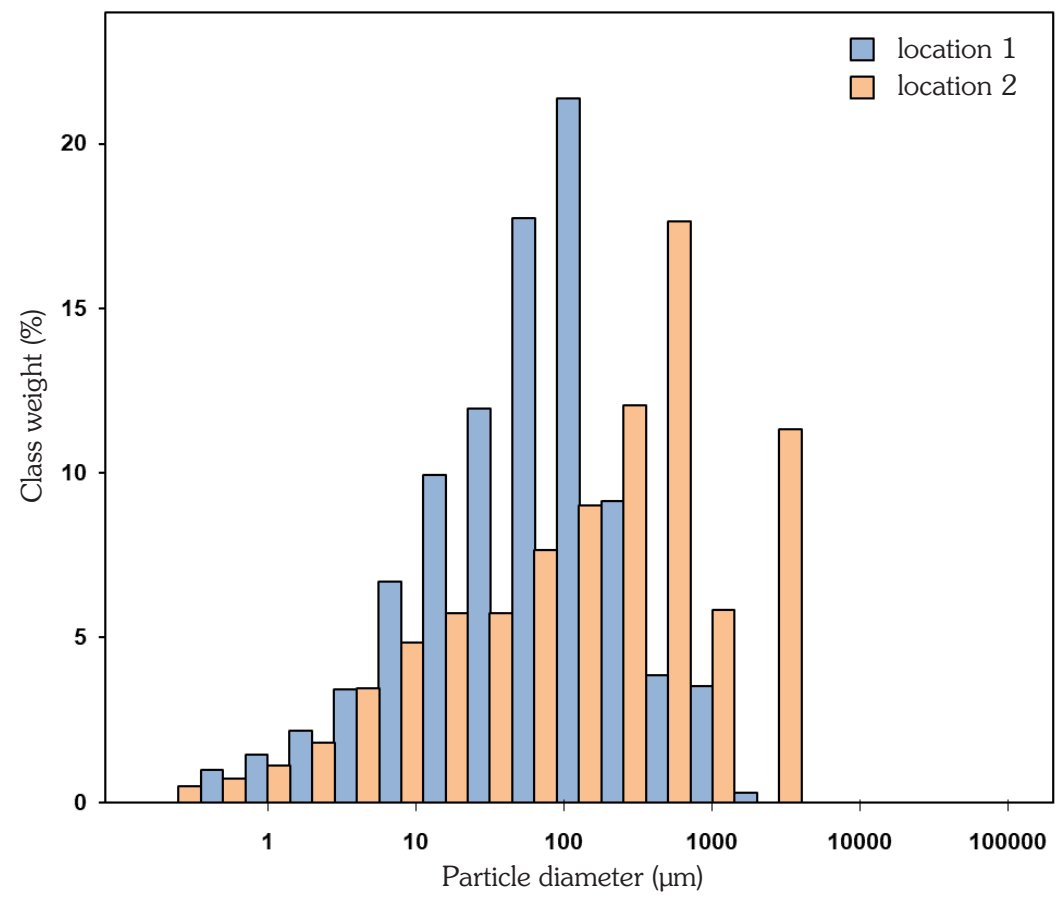

Fig. 2. Grain size distribution in sediments from location 1 and 2. 
Table 1 . The $\mathrm{pH}$ values and mean values of element concentrations in sediment $\left(\mathrm{mg} \mathrm{kg}^{-1}\right)$.

\begin{tabular}{|c|c|c|c|c|c|c|c|c|}
\hline & \multicolumn{3}{|c|}{ Punta Arenas } & \multicolumn{4}{|c|}{ Sediment quality guidelines } & \multirow[t]{2}{*}{ Quintero Bay* } \\
\hline & 1 & 2 & 3 & TEL & PEL & ERL & ERM & \\
\hline $\mathrm{pH}$ & 8.16 & 7.62 & 8.91 & & & & & \\
\hline \multicolumn{9}{|c|}{$\mathrm{mg} \mathrm{kg}^{-1}$} \\
\hline $\mathrm{Ag}$ & 1.30 & 0.43 & 0.44 & & & & & \\
\hline $\mathrm{Al}$ & 94668 & 82513 & 81931 & & & & & $56346-81535$ \\
\hline As & 6.66 & 8.38 & 3.70 & 5.9 & 17.0 & 33 & 85 & $9-20$ \\
\hline $\mathrm{Ba}$ & 358 & 323 & 408 & & & & & $231-476$ \\
\hline $\mathrm{Be}$ & 1.00 & 1.08 & 0.95 & & & & & \\
\hline $\mathrm{Bi}$ & 0.11 & 0.10 & 0.06 & & & & & \\
\hline $\mathrm{Cd}$ & 0.15 & 0.14 & 0.14 & 0.6 & 3.5 & 5 & 9 & \\
\hline Co & 16.0 & 12.2 & 10.7 & & & & & $6-15$ \\
\hline $\mathrm{Cr}$ & 49.6 & 45.0 & 68.3 & 37.3 & 90.0 & 80 & 145 & $27-80$ \\
\hline $\mathrm{Cs}$ & 1.99 & 1.62 & 1.27 & & & & & \\
\hline $\mathrm{Cu}$ & 36.4 & 35.7 & 17.1 & 35.7 & 197 & 70 & 390 & $41-1476$ \\
\hline $\mathrm{Fe}$ & 42693 & 35452 & 31541 & & & & & $26620-94341$ \\
\hline $\mathrm{Li}$ & 30.6 & 26.7 & 21.3 & & & & & $13-21$ \\
\hline $\mathrm{Mn}$ & 813 & 517 & 588 & & & & & $378-1008$ \\
\hline Mo & 1.31 & 1.53 & 0.61 & & & & & $1-8$ \\
\hline $\mathrm{Ni}$ & 24.1 & 22.8 & 25.4 & $18^{*}$ & $36^{*}$ & 30 & 50 & $8-17$ \\
\hline $\mathrm{Pb}$ & 12.0 & 14.1 & 9.45 & 35.0 & 91.3 & 35 & 110 & $17-36$ \\
\hline $\mathrm{Rb}$ & 38.6 & 32.4 & 42.6 & & & & & $40-57$ \\
\hline $\mathrm{Sb}$ & 0.31 & 0.31 & 0.26 & & & & & $1-3$ \\
\hline Sc & 19.0 & 15.6 & 14.3 & & & & & $8-15$ \\
\hline Se & 29.9 & 24.6 & 22.9 & & & & & $<9$ \\
\hline $\mathrm{Sn}$ & 2.01 & 2.01 & 1.66 & & & & & $1-4$ \\
\hline $\mathrm{Sr}$ & 371 & 371 & 446 & & & & & $413-901$ \\
\hline $\mathrm{Ti}$ & 4146 & 3521 & 4572 & & & & & $3218-9545$ \\
\hline $\mathrm{Tl}$ & 0.22 & 0.17 & 0.26 & & & & & \\
\hline $\mathrm{U}$ & 1.35 & 1.62 & 0.93 & & & & & \\
\hline V & 135 & 118 & 115 & & & & & $93-288$ \\
\hline $\mathrm{Zn}$ & 85.1 & 68.0 & 57.7 & 123 & 315 & 120 & 270 & $65-167$ \\
\hline
\end{tabular}

TEL - threshold effect levels (dry weight)

PEL - probable effect levels (dry weight)

ERL - effects range low

ERM - effects range median

* Parra et al. (2015)

ie. from location 1 to location 3, for all measured elements except $\mathrm{Ba}, \mathrm{Cr}, \mathrm{Ni}, \mathrm{Sr}, \mathrm{Rb}, \mathrm{Ti}$ and $\mathrm{Tl}$. For the latter elements, slightly higher concentrations were obtained for marine sediment from location 3. In general, the highest concentrations were obtained for $\mathrm{Al}(81.9$ - $94.7 \mathrm{~g} / \mathrm{kg}), \mathrm{Fe}$ (31.5 - 42.7 $\mathrm{g} / \mathrm{kg})$ and $\mathrm{Ti}(3.52-4.57 \mathrm{~g} / \mathrm{kg})$, while the lowest concentrations were observed for $\mathrm{Bi}(0.06-0.11$ $\mathrm{mg} / \mathrm{kg}), \mathrm{Cd}(0.14-0.15 \mathrm{mg} / \mathrm{kg})$ and $\mathrm{Tl}(0.17-$ $0.26 \mathrm{mg} / \mathrm{kg}$ ) (Table 1). 


\section{Sediment bacteriological composition}

Heterotrophic bacteria were found in abundance of 6.2-6.6 log $\mathrm{CFU} / \mathrm{mL}$ in all three sediment samples (Table 2). The CRB were present in abundance of 1.9 and $2.7 \mathrm{log} \mathrm{CFU} / \mathrm{mL}$ of (Table 2) in river sediments, but they were absent in sediment collected on seashore (sample 3).

Scanning electron microscopy confirmed the presence of randomly distributed bacteria (Fig. 3 ) in the sediment samples where the bacteria were firmly attached to the sediment particles with the signs of biofilm formation.

As shown by MALDI-TOF MS analysis, the $\mathrm{CRB}$ from analysed river sediments were represented by species of the genus Pseudomonas, which are human pathogens with acquired resistance to carbapenems (EUCAST, 2016).

\section{DISCUSSION}

The downstream increase in the average grain size at the mouth of the Río de las Minas and the change from the unimodal to the trimodal particle distribution indicates a change in the yield of the material from relatively homogeneous source of fine-grained material at site 1 to multiple sources, including the impact of the sea, at site 2 (Fig. 1d) or washing of the finest fraction.

Deeply black colour of sediment could be caused by increased content of organic matter or its maturation, after microbial activity. Small variations in ratio between the main mineral components in sediments are also possible due to natural gravitational separation during process of sedimentation.

Table 2. The number of bacteria in sediment samples.

\begin{tabular}{rccc}
\hline & \multicolumn{3}{c}{ Location } \\
\hline Heterotrophic bacteria $(\log$ CFU/mL) & 1 & 2 & 3 \\
\hline Carbapenem-resistant bacteria $(\log$ CFU/mL) & $1.9 \pm 0.0$ & $2.7 \pm 0.0$ & 0 \\
Prevalence of carbapenem-resistant bacteria (\%) & 0.003 & 0.015 & 0 \\
\hline
\end{tabular}
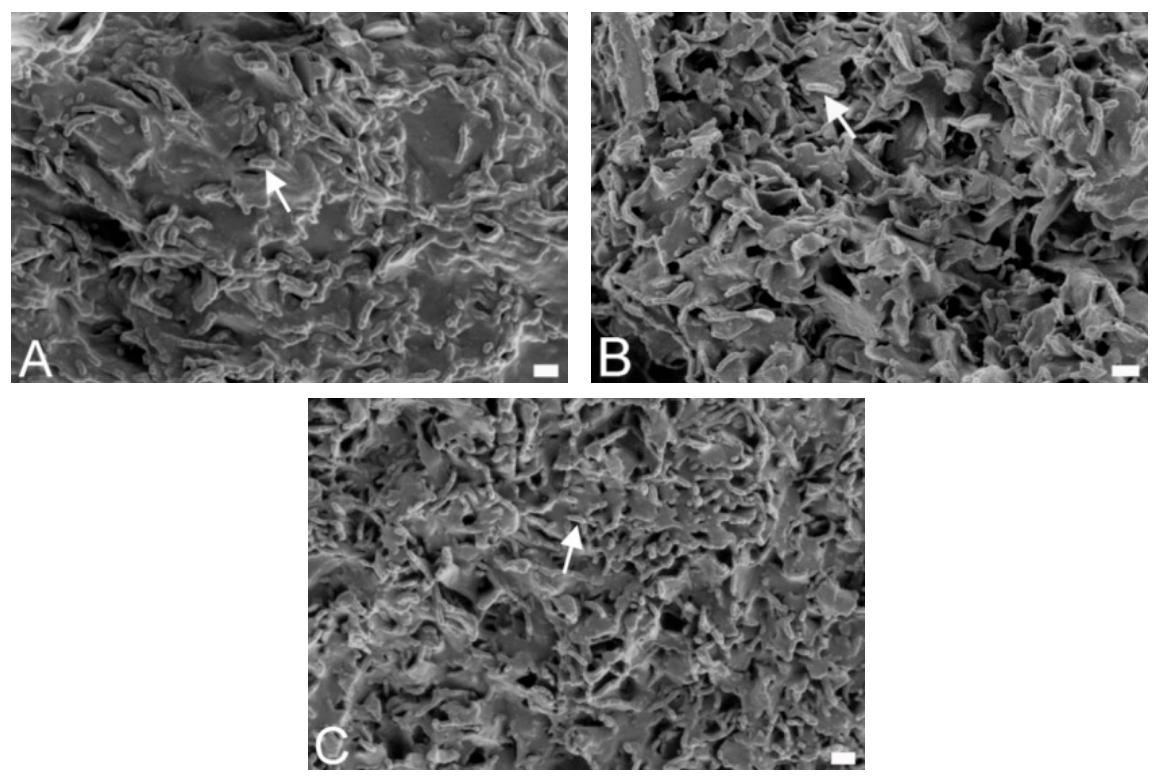

Fig. 3. Scanning electron microscope micrographs indicating the presence of the randomly distributed bacteria (arrows) in sediment at A) Río de las Minas (location 1), B) Río de las Minas (location 2) and C) Strait of Magellan (location 3). Scale bars: 200nm. 
The concentrations of a number of elements in the sediments encompassed by the present study were found in agreement with the data reported by Parra et al. (2015) for sediments from the Quintero Bay in Chile, $2200 \mathrm{~km}$ north of Punta Arenas. Element levels reported by these authors are listed in Table 1 as a range of concentrations found in the bay sediments, whereby the lowest values correspond to the unpolluted reference site and the highest values correspond to sediments polluted by emissions from local industrial sources. In sediments from Punta Arenas, $\mathrm{As}, \mathrm{Cu}, \mathrm{Rb}, \mathrm{Sb}$, and $\mathrm{Pb}$ were found in lower concentrations compared to those reported by Parra et al. (2015), while levels of Fe, $\mathrm{Mo}, \mathrm{Sr}, \mathrm{Ti}, \mathrm{V}, \mathrm{Sn}$, and $\mathrm{Zn}$ correspond to values measured at the reference site in Quintero Bay. On the other hand, $\mathrm{Ba}, \mathrm{Co}, \mathrm{Cr}, \mathrm{Mn}$ and $\mathrm{Sn}$ displayed similar ranges of concentrations in Punta Arenas sediments as those reported by aforementioned authors, while $\mathrm{Al}$ and $\mathrm{Sc}$ concentrations were in accordance with the higher value of listed ranges. Only for $\mathrm{Ni}, \mathrm{Li}$, and $\mathrm{Se}$, measured concentrations in Punta Arenas sediments were higher compared to values reported for the Quintero Bay by Parra et al. (2015).

The Quintero Bay has been subjected to various atmospheric discharges of toxic substances from local industrial sources, contributing to elevated levels of $\mathrm{As}, \mathrm{Cr}, \mathrm{Co}, \mathrm{Cu}, \mathrm{Pb}, \mathrm{Mn}, \mathrm{Mo}$, $\mathrm{Ni}, \mathrm{Se}, \mathrm{V}$ and $\mathrm{Zn}$ in the nearby sediments. While increased levels of $\mathrm{Cu}, \mathrm{Zn}, \mathrm{Se}, \mathrm{Mo}, \mathrm{Sb}$ and $\mathrm{Pb}$ were attributed to $\mathrm{Cu}$-smelting emissions, levels of $\mathrm{Al}$ and $\mathrm{Ba}$ in the bay sediments were linked to aluminosilicate assemblage, and $\mathrm{Fe}, \mathrm{Ti}, \mathrm{Rb}, \mathrm{Sr}$ were considered of lithogenic origin (Parra et al. 2015).

It follows that levels of most elements found in sediments near Punta Arenas reflect natural processes, primarily local geology and grain size distribution. However, the same does not completely apply for $\mathrm{Co}, \mathrm{Cr}, \mathrm{Mn}, \mathrm{Ni}$, Se and $\mathrm{Sb}$, whose levels are most likely additionally influenced by nearby anthropogenic sources.

The obtained concentrations were further compared with the interim freshwater sediment quality guidelines (ISQG) developed by the Canadian Council of Ministers of the Environment (CCME, 2001) consisting of threshold effect levels (TEL) and probable effect levels (PEL). The TEL represents the minimal effect range below which adverse effects rarely occur, while the PEL represents the lower limit of the range of chemical concentrations that are usually or always associated with adverse biological effects. Additionally, the effects range low and effects range median (ERL and ERM), as concentrations in sediments corresponding to the 10th and 50th percentile of the distribution observed in toxic samples, respectively (Long et al. 1995), were used for comparison. Namely, the ERL and ERM are measures of toxicity in marine sediment developed as informal tools to evaluate whether a concentration of a contaminant in sediment might have toxicological effects. However, sediment quality guidelines are usually defined only for a limited set of elements, namely As, $\mathrm{Cd}, \mathrm{Cr}, \mathrm{Cu}, \mathrm{Ni}, \mathrm{Pb}$ and $\mathrm{Zn}$ (Table 1). In studied sediments, $\mathrm{Cd}, \mathrm{Cr}, \mathrm{Pb}$ and $\mathrm{Zn}$ concentrations were lower than the proposed ISQR/TEL values, while $\mathrm{Cu}$ level was the same to slightly higher than the proposed ISQG/TEL value for this element. Only As and $\mathrm{Ni}$ showed slightly higher concentrations compared to ISQG/TEL values, although still much lower compared to PEL values.

To summarize, geochemistry of sediments near Punta Arenas reflects the influence of both the natural processes and anthropogenic activity. Although the concentrations of all elements, even As and $\mathrm{Ni}$ which are just above the TEL levels, are still at levels that do not represent a toxic effect on the present organisms, the human impact on the sediment composition in the study area cannot be denied. Although the size of the data set precludes further discussion on the origin of these elements in sediments of the Río de las Minas, pipe systems made of galvanized material or application of paints containing $\mathrm{Cu}, \mathrm{Pb}$, etc., may be some of the reasons for the observed levels of mentioned elements. However, the impact of human activity on heavy metal(loid) budget in the Río de las Minas estuarine sediments should be studied in more detail not only for purposes of determining their origin but also for their possible interaction with microbial community.

Namely, in studied sediments the CRB were present in abundance of 1.9 and $2.7 \log$ CFU/ $\mathrm{mL}$, whereas Marathe et al. (2017) reported up to $7.9 \log \mathrm{CFUs} / \mathrm{gram}$ of sediment of carbapenemresistant strains for Mutha River sediments, collected near a hospital wastewater discharge 
site in the Pune city (India). Pune city is the ninth largest city in India with a population of around 5.9 million, while the Mutha River, flowing through the city, is one of the most polluted rivers in the state of Pune. Although the city has several sewage treatment plants, up to $64 \%$ of the sewage enters the river untreated (Narain et al. 2012). Compared to Punta Arenas, Pune city is significantly larger, which necessarily entails more intensive and diverse anthropogenic pressures; and thus the significantly higher prevalence of CRBs in the sediments of the Mutha River compared to the Río de las Minas was expected.

Observed prevalence of $\mathrm{CRB}$ among total heterotrophic bacteria $(0.003 \%$ at location 1 and $0.015 \%$ at location 2 ) is, on the other hand, comparable to the prevalence of CRB $(0.001$ - $0.005 \%$ ) in the river sediments influenced by untreated urban wastewaters in Croatia, but lower than $1.1 \%$ reported in the river sediments influenced by untreated hospital wastewater (Hrenović et al. 2019). The abundance of CRB represented by carbapenem-resistant Pseudomonas sp. suggests the moderate impact of hospital and urban wastewaters on the Río de las Minas.

Kovačić et al. (2017) studied the transmission and survival of carbapenemresistant Acinetobacter baumannii outside the hospital setting. They reported $55-67 \%$ survival of A. baumannii in seawater during 50 days of monitoring. No multiplication of bacteria was observed as compared to initial numbers. The absence of bacterial multiplication was explained by low nutrient concentration in natural seawater (Kovačić et al. 2017). The latter, in addition to dissemination with existing currents and the overall dilution in the marine environment, could be the reason for the absence of $\mathrm{CRBs}$ in the Punta Arenas seashore sediment (location 3). However, the scarcity of literature data precludes broader discussion. Namely, the CRB of clinical importance are not routinely measured in water or in sediments, although the presences of CRB in the environment possess the public-health risk. The European Union allows a maximum of 500 E. coli CFU/100 mL in seawater for recreational use (European Union, 2007), whereas the Environmental Protection Agency allows a maximum of $200 \mathrm{E}$. coli CFU/100 mL in water bodies used for recreational purposes (EPA, 1986). The Chilean guidelines are even less strict, allowing a maximum of 1000 faecal coliform CFU/100 mL in recreational water with direct human contact (NCh 1333 Of. 78). Despite the knowledge that estimation of microbial contaminants in sediments can serve as a stable index for long-term water quality risks, microbiological guidelines for sediments are currently nonexistent.

The necessity of further research on this topic, combining both geochemical and microbiological parameters, also prompts the fact that the co-selection represents an upcoming risk to human health due to the development of metal driven multiple antibiotic resistant bacterial pathogens. Namely, Imran et al. (2019) recently concluded in their review that co-contamination of the environment with metals, microplastics and antibiotics results in the development and spread of multiple-drug-resistant human pathogens through the co-selection mechanism. Due to the possible emergence of metal driven multiple drug resistant human pathogens associated with microplastics, co-contamination of terrestrial and aquatic environments with metal and microplastic is becoming a global concern.

\section{CONCLUSION}

Even restricted number of sediments collected and analysed from Río de las Minas reflects the influence of natural processes and anthropogenic activities in the Punta Arenas area. The geochemistry of the investigated sediments mainly reflects the geological background and grain size distribution at the mouth of the river. However, some of the elements point to the influence of additional sources on the sedimentary metal budget, indicating a clear track record of human activities in the region. Although metal levels currently do not present a toxic effect on present organisms, the anthropogenic impact on sediment composition is evident. Along with elevated levels of some metals, such as arsenic and nickel, untreated urban wastewaters represent a source of clinically relevant carbapenem-resistant bacteria. According to our knowledge, these are the first data that combine sedimentary geochemistry with microbiological contaminants in southernmost 
regions and represent the basis for further, more extensive studies of multiple-drug-resistant human pathogens and their co-selection with existing metals in the environment. Further comprehensive studies involving the upper parts of the river are also welcome.

\section{ACKNOWLEDGEMENTS}

This study was financed by the Erasmus+ programme and in a part by the Croatian Science Foundation (project no. IP-2014-09-5656).

\section{LITERATURE CITED}

APHA, AWWA, \& WEF (2005). Standard Methods for the Examination of Water and Wastewater (21st edn.). New York: American Public Health Association

Blott, S. J., \& Pye, K. (2001). GRADISTAT, A grain size distribution and statistics package for the analysis of unconsolidated sediments: Earth Surface Processes and Landforms, 26, 1237-1248.

Bonnedahl, J., Olsen, B., Aldenstrom, J., Broman, T., Jalava, J., Huovinen, P., \& Osterblad, M. (2008). Antibiotic susceptibility of fecal bacteria in Antarctic penguins. Polar Biology, 31, 759-763.

CAMS (2016). Antibiotic Resistance in Croatia, 2015. The Croatian Academy of Medical Sciences (pp. 52-54). Zagreb.

CCME (2001). Canadian environmental quality guidelines for the protection of aquatic life, CCME water quality index, technical report, 1.0 .

Chandran, S. P., Diwan, V., Tamhankar, A. J., Joseph, B. V., Rosales-Klintz, S., Mundayoor, S., Lundborg, C. S., \& Macaden, R. (2014). Detection of carbapenem resistance genes and cephalosporin, and quinolone resistance genes along with oqx $\mathrm{AB}$ gene in Escherichia coli in hospital wastewater: a matter of concern. Journal of Applied Microbiology, 117, 984-995.

Cowan, D. A., Chown, S. L., Convey, P., Tuffin, M., Hughes, K., Pointing, S., \& Vincent, W. (2011). Non-indigenous microorganisms in the Antarctic: assessing the risks. Trends in
Microbiology, 19, 540-548.

Delille, D., \& Delille, E. (2000). Distribution of enteric bacteria in Antarctic seawater surrounding the Dumont d'Urville permanent station (Adelie Land). Marine Pollution Bulletin, 40, 869-872.

Delille, D., \& Gleizon, F. (2003). Distribution of enteric bacteria in Antarctic seawater surrounding the Port-aux-Francais permanent station (Kerguelen Island). Marine Pollution Bulletin, 46, 11791183.

Devarajan, N., Laffite, A., Ngelikoto, P., Elongo, V., Prabakar, K., Mubedi, J.I., Piana, P. T., Wildi, W., \& Poté, J. (2015). Hospital and urban effluent waters as a source of accumulation of toxic metals in the sediment receiving system of the Cauvery River, Tiruchirappalli, Tamil Nadu, India. Environmental science and pollution research international, 22(17), 12941-12950.

Devarajan, N., Laffite, A., Mulaji, C. K., Otamonga, J.-P., Mpiana, P. T., Mubedi, J. I., Prabakar, K., Ibelings, B. W., \& Poté, J. (2016). Occurrence of Antibiotic Resistance Genes and Bacterial Markers in a Tropical River Receiving Hospital and Urban Wastewaters. PLoS ONE 11(2), e0149211.

EPA (1986). Ambient Water Quality Criteria for Bacteria. Environmental Protection Agency, 440-5-84002.

European Union (2007). Ministerio de la Presidencia. Real Decreto 1341/2007 (pp. 43620-43629). BOE núm. 257.

EUCAST (2016). Expert rules, intrinsic resistance and exceptional phenotypes $\mathrm{V}$ 3.1 (Sept 27, 2016). European Committee on Antimicrobial Susceptibility Testing.

Ferreira, A. E., Marchetti, D. P., De Oliveira, L. M., Gusatti, C. S., Fuentefria, D. B., \& Corcao, G. (2011). Presence of OXA-23-producing isolates of Acinetobacter baumannii in wastewater from hospitals in southern Brazil. Microbial Drug Resistance, 17, 221-227.

Fiket, Ž., Mikac, N., \& Kniewald, G. (2017). Mass Fractions of Forty-Six Major and Trace Elements, Including Rare Earth Elements, in Sediment and Soil Reference Materials Used in Environmental Studies. Geostandards 
and Geoanalytical Research, 41(1), 123135.

Folk, R. L., \& Ward, W. C. (1957). Brazos river bar: a study in the significance of grain size parameters. Journal of Sedimentary Petrology, 27, 3-26.

Goossens, H., Ferech, M., Stichele, R. V., \& Elseviers, M. (2005). Outpatient antibiotic use in Europe and association with resistance: A cross-national database study. Lancet, 365, 579-587.

Haller, L., Pote, J., Loizeau, J. L., \& Wildi, W. (2009). Distribution and survival of faecal indicator bacteria in the sediments of the Bay of Vidy, Lake Geneva, Switzerland. Ecological Indicators, 9(3), 540-547.

Hellman, J., Aspevall, O., Bengtsson, B., \& Pringle, M. (2014). SWEDRES-SVARM2014. Consumption of Antimicrobials and Occurrence of Antimicrobial Resistance in Sweden (No.14027). Public Health Agency of Sweden and National Veterinary Institute, Solna/Uppsala, Sweden.

Hrenović, J., Ganjto, M., \& Goić-Barišić, I. (2017a). Carbapenem-resistant bacteria in a secondary wastewater treatment plant. Water SA, 43, 186-191.

Hrenović, J., Ivanković, T., Iveković, D., Repec, S., Stipaničev, D., \& Ganjto, M. (2017b). The fate of carbapenem-resistant bacteria in a wastewater treatment plant. Water Research, 126, 232-239.

Hrenović, J., Durn, G., Kazazić, S., Dekić, S., \& Šeruga Musić, M. (2019). Untreated wastewater as a source of carbapenemresistant bacteria to the riverine ecosystem. Water SA, 45(1), 55-62.

ICDD Powder Diffraction File (2004). Database Sets 1-54. International Centre for Diffraction Data (ICDD), Newtown Square, Pennsylvania, USA.

Imran, M., Das, K. R., \& Naik, M. M. (2019). Coselection of multi-antibiotic resistance in bacterial pathogens in metal and microplastic contaminated environments: an emerging health threat. Chemosphere, 215, 846857.

Kovačić, A., Šeruga Musić, M., Dekić, S., Tonkić, M., Novak, A., Rubić, Ž., Hrenović, J.,
\& Goić-Barišić, I. (2017). Transmission and survival of carbapenem-resistant Acinetobacter baumannii outside hospital setting. International Microbiology, 20(4), 165-169.

Kristiansson, E., Fick, J., Janzon, A., Grabic, R., Rutgersson, C., Weijdegård, B., Söderström, H., \& Larsson, D.G.J. (2011). Pyrosequencing of Antibiotic-Contaminated River Sediments Reveals High Levels of Resistance and Gene Transfer Elements. PloS One, 6(2), e17038.

Long, E.R., MacDonald, D.D., Smith, S.L., \& Calder, F.D. (1995). Incidence of adverse biological effects within ranges of chemical concentrations in marine and estuarine sediments. Environmental Management, 19(1), 81-97.

Marathe, N. P., Pal, C., Gaikwad, S. S., Jonsson, V., Kristiansson, E., \& Larsson, D. G. J. (2017). Untreated urban waste contaminates Indian river sediments with resistance genes to last resort antibiotics. Water Research, 124(1), 388-397.

Marathe, N. P., Janzon, Kotsakis, S. D., Flach, C.F., Razavi, M., Berglund, F., Kristiansson, E., \& Larsson, D. G. J. (2018). Functional metagenomics reveals a novel carbapenemhydrolyzing mobile beta-lactamase from Indian river sediments contaminated with antibiotic production waste. Environment International, 112, 279-286.

Meletis, G. (2016). Carbapenem resistance: overview of the problem and future perspectives. Therapeutic Advances in Infectious Disease, 3, 15-21.

Mwanamoki, P. M., Devarajan, N., Thevenon, F., Atibu, E. K., Tshibanda, J. B., Ngelinkoto, P., Mpiana, P. T., Prabakar, K., Mubedi, J. I., Kabele, C. G., Wildi, W., \& Poté, J. (2014). Assessment of pathogenic bacteria in water and sediment from a water reservoir under tropical conditions (Lake Ma Vallee), Kinshasa Democratic Republic of Congo. Environmental monitoring and assessment, 186(10), 6821-6830.

Narain, S.P.P., Banerjee, S., \& Chaudhuri, J. (2012). Excreta Matters: How Urban India 
Is Soaking up Water, Polluting Rivers and Drowning in its Own Waste. Centre for Science and Environment, India, New Delhi.

NCh 1333 Of. 78. Norma chilena sobre requisitos de calidad del agua para diferentes usos. Norma Decreto Supremo http://ciperchile. cl/pdfs/11-2013/norovirus/NCh13331978_Mod-1987.pdf.

Obayiuwana, A., Ogunjobi, A., Yang, M., \& Ibekwe, M. (2018). Characterization of Bacterial Communities and Their Antibiotic Resistance Profiles in Wastewaters Obtained from Pharmaceutical Facilities in Lagos and Ogun States, Nigeria. International Journal of Environmental Research and Public Health, 15, 1365.

Parra, S., Bravo, M.A., Quiroz, W., Querol, X., \& Paipa, C. (2015). Distribution and pollution assessment of trace elements in marine sediments in the Quintero Bay (Chile). Marine Pollution Bulletin, 99(1-2), 256263.

Pote, J., Bravo, A.G., Mavingui, P., Ariztegui, D., \& Wildi, W. (2010). Evaluation of quantitative recovery of bacterial cells and DNA from different lake sediments by Nycodenz density gradient centrifugation. Ecological Indicators, 10(2), 234-240.

Rabbia, V., Bello-Toledo, H., Jiménez, S., Quezada, M., Domínguez, M., Vergara, L., Gómez-Fuentes, C., Calisto-Ulloa, N., González-Acuña, D., López, J., \& GonzálezRocha, G. (2016). Antibiotic resistance in Escherichia coli strains isolated from Antarctic bird faeces, water from inside a wastewater treatment plant, and seawater samples collected in the Antarctic Treaty area. Polar Science, 10(2), 123-131.

Reczynski, W., Jakubowska, M., Golas, J., Parker, A., \& Kubica, B. (2010). Chemistry of sediments from the Dobczyce Reservoir, Poland, and the environmental implications. International Journal of Sediment Research, 25, 28-38.

Seiler, C., \& Berendonk, T. U. (2012). Heavy metal driven co-selection of antibiotic resistance in soil and water bodies impacted by agriculture and aquaculture. Frontiers in Microbiology, 14(3), 399.
Šeruga Musić, M., Hrenović, J., Goić-Barišić, I., Hunjak, B., Škorić, D., \& Ivanković, T. (2017). Emission of extensively-drug resistant Acinetobacter baumannii from hospital settings to the natural environment. Journal of Hospital Infection, 96, 232237.

Shepard, F. P. (1954). Nomenclature based on sand-silt-clay ratios. Journal of Sedimentary Petrology, 24, 151-158.

Skurnik, D., Ruimy, R., Andremont, A., Amorin, C., Rouquet, P., Picard, B., \& Denamur, E. (2006). Effect of human vicinity on antimicrobial resistance and integrons in animal faecal Escherichia coli. Journal of Antimicrobial Chemotherapy, 57, 12151219.

Spindler, A., Otton, L. M., Fuentefria, D. B., \& Corcao, G. (2012). Beta-lactams resistance and presence of class 1 integron in Pseudomonas spp. isolated from untreated hospital effluents in Brazil. Antonie van Leeuwenhoek, 102(1), 73-81.

Thevenon, F., Adatte, T., Wildi, W., \& Pote, J. (2012). Antibiotic resistant bacteria/genes dissemination in lacustrine sediments highly increased following cultural eutrophication of Lake Geneva (Switzerland). Chemosphere, 86(5), 468-76.

WHO (2015). Antimicrobial Resistance: Global Report on Surveillance 2014; World Health Organization: Geneva, Switzerland, 2015.

WHO (2017). World Health Organization website, http://www.who.int/ medicines/publications/WHO-PPLShort_Summary_25Feb-ET_NM_WHO. pdf?ua $1 / 41$, World Health Organization.

Zhang, C., Qiu, S., Wang, Y., Qi, L., Hao, R., Liu, X., Shi, Y.,... \& Song, H. (2013). Higher isolation of NDM-1 producing Acinetobacter baumannii from the sewage of the hospitals in Beijing. PLoS One, 8, e64857.

Zheng, N., Wang, Q., Liang, Z., \& Zheng, D. (2008). Characterization of heavy metal concentrations in the sediments of three freshwater rivers in Huludao City, Northeast China. Environmental Pollution, 154, 135-142. 
